\title{
MULTILEVEL GOVERNANCE IN SOUTH AMERICA: BORDERLINE MERCOCITIES AND MERCOSUR REGIONAL INTEGRATION
}

\author{
GOVERNANÇA MULTINÍVEL NA AMÉRICA DO SUL: MERCOCIDADES FRONTEIRIÇAS E \\ A INTEGRAÇÃO REGIONAL DO MERCOSUL
}

Leonardo Mèrcher ${ }^{1}$

Glaucia Julião Bernardo²

Evelise Zampier Silva Correio ${ }^{3}$

\begin{abstract}
Based on data collection about national borders in South America, it was possible to observe that cities started to play an important role in public policies for regional integration. In order to understand these agents and how multilevels of governance in borderlines agendas are working on, the following analysis were conducted by: i) the mapping scenario of borderlines cities in South America; ii) and the Mercocities Network as an example of multilevel governance in the current process of regional integration of borderlines agendas. The results show that, despite the existing shared knowledge about public policies among SouthAmerican cities, the Mercocities Network also changes the political dynamic in the region by transferring part of border integration responsibilities from MERCOSUR national States to cities.
\end{abstract}

Keywords: Cities; Borderlines; Governance; Mercocities; Integration.

\section{Resumo}

Baseado na coleta de dados referentes às fronteiras nacionais da América do Sul, é possível observar que cidades alcançam destaque no âmbito das políticas públicas de integração regional. Para compreender esses agentes e como novos níveis de governança estariam funcionando nas agendas fronteiriças, a presente análise é conduzida: i) pelo mapeamento do cenário das cidades fronteiriças na América do Sul; ii) da Rede de Mercocidades como exemplo de governança multinível no atual processo de integração regional das agendas fronteiriças. Os resultados obtidos indicam que, apesar da Rede de Mercocidades compartilhar experiências sobre políticas públicas entre suas cidades-membros, a Rede também transformaria dinâmicas políticas na região por meio da transferência de responsabilidades da integração dos Estados-membros do MERCOSUL para as cidades.

Palavras-Chave: Cidades; Fronteiras; Governança; Mercocidades; Integração.

\footnotetext{
1 Pós-doutorando em Ciência Política na UFPR e na UNRAF e Doutor em Ciência Política pela Universidade Federal do Paraná. Professor de Relações Internacionais e Artes Visuais no Centro Universitário Internacional - UNINTER. E-mail: Imercher@uol.com.br. ORCID: https://orcid.org/0000-0003-1812-7803.

${ }^{2}$ Doutoranda em Políticas Públicas pela UFPR, com Mestrado em Políticas Públicas pela UFPR (2015) e especialização em Gestão e Liderança Educacional pela FAE (2011). E-mail: glaubernardo@gmail.com. ORCID: https://orcid.org/0000-0003-1812-7803.

${ }^{3}$ Doutoranda em Ciência Política pela Universidade Federal do Paraná e Mestre em Gestão Urbana pela Pontifícia Universidade Católica do Paraná. E-mail: zampierdasilva@gmail.com. ORCID: https://orcid.org/0000-0002-6615-3187.
} 


\section{INTRODUCTION}

South America is undergoing several regional integration processes. However, many of the demands of these processes are not met by national governments, either due to institutional distance or to lack of interest. The aim of this article is to identify the current situation of the integration in South America based on the collection of data about network actions from conurbation border cities. This theme was chosen due to the capacity showed by the cities of acting in relation to subjects ignored by national governments, as well as of exchanging experiences and creating new dynamics to regional integration processes on the continent: as multilevel governance.

Cities in national border areas have their own socio-political dynamic, since they are located at the interface between local, national and international jurisdictions. This is a context in which tensions imposed by territorial limits, relations of interdependence and cooperation coexist. The study of conurbation border cities is relevant in the field of International Relations, since it evidences the intersection of governmental/transnational actions and the creation of their own mechanisms of action and international insertion.

In relation to how subnational governments deal with neighboring governments, as well as with the different international dynamics that affect their development projects, ILADIR presents an organization chart (see Figure 1):

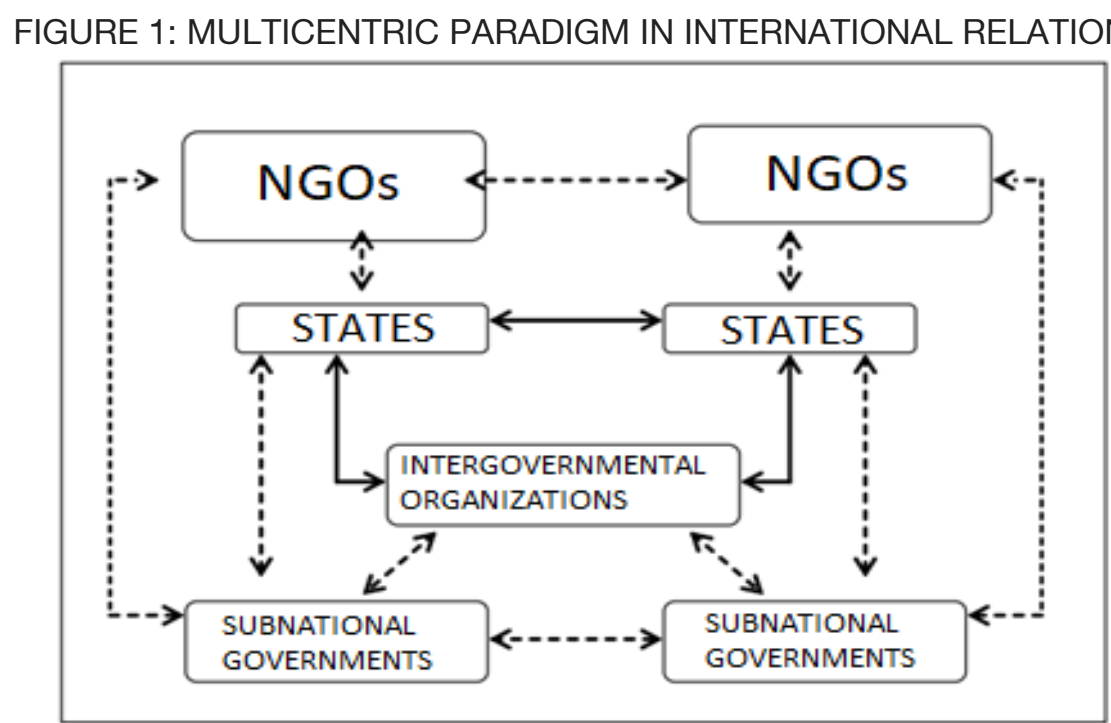

Source: ILADIR 2011, 6.

This multicentric organization chart (Figure 1) shows the increasing relevance and recognition of new agents and their respective roles in contemporary International Relations. According to it, States and their international organizations open new ways for the improvement 
of their agendas and for the participation of new agents playing a variety of roles, such as civil societies and local governments. In the case of local governments, we note the consolidation of intergovernmental organizations organized in city networks. City networks interact and interfere in national decisions by means of the regional integration process, which we will show later in this paper. Specifically in South America, city networks have also become a means for development when the cities' concerned are located in border areas.

Our decision was to only analyze border areas in South America focusing on conurbations, which were identified through satellite imagery. We have identified 53 conurbation areas altogether, composed of two or more cities in each bordering country (Figure 3). A database was then created containing the following information: location of the conurbation area; demographic density; nationality of each city in the conurbation area; name of the border region in South America (to know which regional integration process it is linked to); and participation in local city networks.

In South America, only three regional city networks deal with regional integration processes: Mercocities Network, REDCISUR and Red Andina de Ciudades. Considering the number of associated cities, the largest of them is the Mercocities Network. Mercocities was founded in 1995 and has today a total of 340 associated cities from ten countries in South America (Mercocidades 2018a). According to our database, cities in border conurbation areas are significantly represented in Mercocities, and some of them, such as Asunción, Uruguaiana, Itaqui and Santa Vitória do Palmar, even contributed to the creation of the Unidade Temática de Integração Fronteiriça (Border Integration Workgroup, UTIF) in 2013 (Mercocidades 2018m). Therefore, our decision was to analyze border cities' actions in all sixteen Mercocities workgroups, reviewing 524 documents (minutes, work plans, reports, etc.) from 1995 (Mercocities foundation) until today (Mercocidades 2018a). The aim was to identify initiatives from these cities concerning the process of cooperation and regional integration along border areas. It is important to highlight that, in order to do this research, other sources were used beyond the official Mercocities documents, such as interviews and other government and international documents.

Since our general objective was to understand these agents and how these new levels of government coordination change the integration in border regions, this article was divided in three sections related to the creation of our database: i) identification of border cities and their agendas, such as participation in city networks; ii) the multilevel governance by iniciatives from Mercocities Network in the current process of MERCOSUR regional integration; and iii) the final considerations over our database and personal insights. 


\section{SOUTH AMERICAN BORDERLINES: FROM NATIONAL TO CONURBATION CITIES AGENDAS}

South American national borders have been historically constructed by disputes in three distinct geographic regions (Figure 2): Andean (West); Amazon (North); and La Plata (South). After their Independence processes, some nations, such as Bolivia, Chile and Peru, were engaged in armed conflicts, because they disagreed with the demarcation of their borders. Argentina and Brazil also engaged in conflicts that resulted in the formation of Uruguay and in the largest international armed conflict in South America, the Paraguayan War (1864-1870). These various conflicts left their mark on the South American nations, which began to regard borders as spaces of dispute and as a matter of national security.

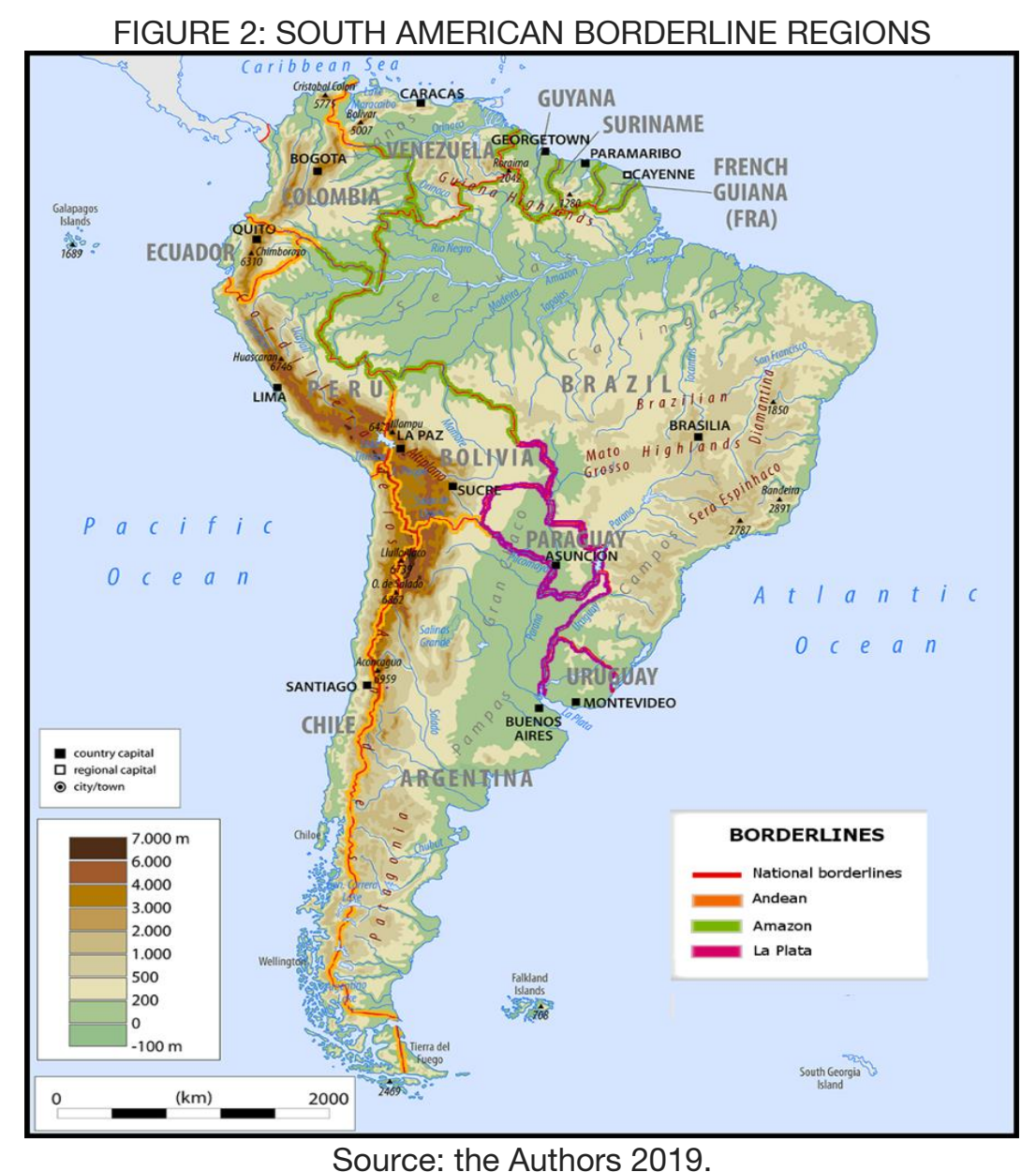

Even though territorial conflicts have been attenuated in international judicial proceedings, many other challenges involving South American borders still exist. Disputes among farmers over the exploitation of neighboring lands, such as the Brazilian agrarian expansion over Paraguay and Bolivia (brasiguaios), trafficking of arms, drugs and animals, as well as deforestation, migration flows and a lack of control over armed groups ( $F A R C$, in Colombia) all give rise to the perception 
of borders as a challenging space for public management. These challenges have been addressed collectively and cooperatively by many national governments that, through regional integration processes, have created programs and incentives for the development and integration of border regions.

In the past few decades, several processes of regional integration have been initiated in South America, such as ALALC (1960), ALADI (1980), Andean Pact (1969), MERCOSUR (1991) and UNASUL (2008). With respect to subnational governments, these regional integration organizations have contributed to increasing the number of channels of communication and to the guiding of joint projects. For example, MERCOSUR (Argentina, Brazil, Paraguay, Uruguay and Venezuela) created the Foro Consultivo de Municípios, Estados Federados, Províncias e Departamentos do Mercosul (Consultative Forum of Municipalities, Federal states, Provinces and Departments of the MERCOSUR, FCCR). With respect to border regions, the FCCR has a Border Integration Workgroup, where local and national authorities plan joint actions to consolidate the process of regional integration. As a result, several regions of cross-border cooperation (the socalled Merco-regions) were created.

MERCOSUR also has institutionally recognized the Mercocities Network, which was created in 1995 by 11 cities: Rosario (Argentina), Asunción (Paraguay), Florianópolis (Brazil), Porto Alegre (Brazil), La Plata (Argentina), Curitiba (Brazil), Rio de Janeiro (Brazil), Brasília (Brazil), Córdoba (Argentina), Salvador (Brazil) and Montevideo (Uruguay). According to the UCLG (UCLG 2016), Argentina, Brazil, Canada and the USA are the countries offering the greatest degree of flexibility and the highest level of incentives when it comes to the independent action of subnational governments in the Americas. In South America, this can be explained by the Argentinean constitutional reforms and by the Brazilian institutional reforms implemented by these countries during the 1990s. Whereas Bolivia, Colombia, Peru and Uruguay all went through intermediate decentralization processes, in Chile, Ecuador, Paraguay and Venezuela traditionally their subnational governments have not participated much in international relations. However, over the past decade, Chile has been encouraging their subnational governments to be more proactive as a part of the national government policy (ILADIR 2011, 20). Specifically, regarding border cities and regional integration, Castello says:

It is certainly at the regional level, in areas that have long since been guaranteeing national boundaries and practicing actual integration, that the effects and pressures arising from the integration process will also be felt on local societies and on the spaces they engender. The duality of frontier spaces is a very evident feature, made clear, on the one hand, by the need to establish separations and limits in the name of cultural differences and of the preservation of national sovereignty and, on the other hand, by social practices and exchanges which, in face of physical proximity and common interests, are established. The border is, at one and the same time, an area of separation and approximation, a barrier line 
and a polarizing space. It is, above all, a space of tensions, of coexistence of differences, and of the establishment of new sociocultural realities. From the political point of view, the frontier is a strip, a Great Wall of China, an imposed cut, to be crossed and overthrown as a result of the contemporary perspective, which stimulates the formation of supranational economic blocks. (Castello 1995, 15, our translation)

In order to solve the paradox of borders being at the same time a challenge and a means for regional integration, networking and multilevel governance arrangements both present promising solutions. New dynamics have changed the perception of the border: the emphasis on its security aspects, present during the period of the military dictatorships of the 1950s and 1980s, have been replaced by new priorities in which ideas of integration and cooperation have come to the fore, in addition to the prioritization of the construction of new models for public policies (Carneiro Filho 2016).

For example, the Programa de Desenvolvimento da Faixa de Fronteira (Border Zone Development Program, PDFF) of the Ministry of National Integration of Brazil was based on the National Policy for Regional Development and reflects an increase in international cooperative relations. This program even affected border city communities beyond the Brazilian border lines, as acknowledged by the Brazilian government in its proposal for the regulation of the relations with neighboring countries based on local rules (Brasil 2009, 6-20).

A national/central solution to improve local autonomy was the creation and consolidation of binational border committees (Brasil 2009, 20), through which the particularities of different regions could be worked out. One of the results of these committees is the development of the Programa Escolas Interculturais de Fronteira (Intercultural Border Schools Program, PEIF), which was focused on the La Plata region between Brazil and Uruguay. The courses offered by this program take place in the border cities of Santana do Livramento (RS, Brazil), Rivera (Uruguay), Jaguarão (RS, Brazil) and Rio Branco (AC, Brazil). Professor Lia Pachalski, the International Relations adviser from the Instituto Federal de Educação, Ciência e Tecnologia Sul-rio-grandense (Federal Institute of Education, Science and Technology of Rio Grande do Sul, IFSul) responsible for the development of the project reported to us:

(...) it was a response that we gave to a demand from the MEC [Ministry of Education of Brazil]. They [MEC] made the provocation based on the successful projects that happened in 2007, 2008 and 2009 organized by the Cooperation Agency of Brazil. And then, as they were aligning macro policies [between] Brazil and Uruguay, (...) they decided to start with the education area, to invest in the area of education, within a proposal of the Ministry of Integration, which also discussed other possibilities of integration in the area of health, environment, at those high-level meetings. Then, it [Intercultural Border Schools Program] was proposed by the government itself: by the Ministry of Foreign Affairs and by the Ministry of Integration. (our translation of an interview originally in Portuguese) 
This passage illustrates the engagement of both Brazilian and Uruguayan national governments in the project. However, this project was made possible due to the interaction of national and subnational governments. Again, in Lia Pachalski words:

The Ministry of Integration [of Brazil] had a program (...) Border Zone Development Program, and it worked as a gear inside the states and the municipalities. So they had units in each city, where the mayor was responsible for gathering authorities and border representatives to collect demands. In fact, it was a smooth integration between the cities and the federal government, which generated this demand as well. So, it is really a very broad project from the Ministry of Integration, the Ministry of Foreign Relations and MEC, after all. (Our translation of an interview originally in Portuguese)

In addition to the integrated actions between national governments, states/provinces and municipalities/cities, the project relied on the engagement of local teachers, communities and managers. This group was responsible for implementing the project and demanding solutions, and also had to deal with the daily hardships involved in merging the teaching practices and in the recognition and institutionalization of the binational vocational education. Therefore, the multilevel participation of national governments, their subnational governments and their respective neighbors usually occurs in order to meet local demands manifested in primary services such as sanitation, education, development and social rights.

As stated by Anne Marie Slaughter (2008), the State is composed of smaller parts, not only of a national government. In South America, many cities initiated regional activities through the creation of networks linked to the regional integration process. Some of them are international and transcontinental, such as United Cities and Local Governments (UCLG), Local Governments for Sustainability (ICLEI), União de Cidades Capitais Ibero-americanas (Union of Ibero-American Capital Cities, UCCI), URB-AL Programme (the urban cooperation programme of the EU) and Centro Iberoamericano de Desarrollo Estratégico Urbano (Ibero-American Centre for Strategic Urban Development, CIDEU). Some of them are only regional, such as Federación Latinoamericana de Ciudades, Municipios y Asociaciones Municipalistas (Latin American Federation of Cities, Municipalities and Associations, FLACMA, UCLG's regional office), Red de Ciudades Suramericanas (South American Cities Network, REDCISUR), Rede de Mercocidades (Mercocities Network, the largest city network in South America) and Red Andina de Ciudades (Andean Network of Cities, RAC). Other city networks are intranational and are able to negotiate directly with their own national governments, such as Federación Argentina de Municípios (Argentine Federation of Municipalities, FAM), Associação Brasileira de Municípios (Brazilian Association of Municipalities, ABM), Confederação Nacional de Municípios (National Confederation of Municipalities, CNM, Brazil), Frente Nacional de Prefeitos (National Front of Mayors, FNP, Brazil) and Red de Ciudades Cómo Vamos (Cómo Vamos City Network, Colombia). 
In the same way, governance processes bring together various governmental and nongovernmental actors that favor organization and the achievement of common goals. Thus, cities become agents of the regional integration agenda, relevant to national gains as well as to an entire region. Sassen (1996) points out that globalization leads to an adaptation of pre-existing institutions, allowing actors such as cities to exercise new functions in structures more specialized and less hierarchical in relation to the Westphalian Order. In this new structure, national states focus on high politics in order to control and regulate the global capitalist economy from a macro perspective, while subnational governments - isolated or in a network seek to answer local demands. In the same sense,

(...) the processes of globalization and regional integration ceased to be State policies to be incorporated into the daily life of localities, directly influencing the performance of subnational governments. Consequently, there was a redefinition of its very own role and of its role in the international arena, especially in the case of integrationist processes. (Mariano and Mariano 2005, 148, our translation).

According to Rosenau and Czempiel (2000), as a result of the dynamics of globalization, centers of authority are delegated to supranational and subnational entities, since national governments cannot handle alone all the presented demands. This reallocation is a turning point on the "reconfiguration of authority" process in different decision-making centers, either in different territorial units or through the division of competencies in themes or in differentiated functionalities from multilevel governance processes (Hooghe and Marks, 2003). Therefore, Sassen (1996), Rosenau \& Czempiel (2000) and Slaughter (2008) contribute to the understanding that city networks fit into a scenario of greater proximity to local challenges, complementing the process of multilevel governance. Since the South American subnational governments scenario is also marked by an increase of actions in multilevel governance, it is important to identify how the cities of the region are reacting to it. Above all, we aim to identify what border cities are building autonomously and how they contribute to multilevel governance arrangements in South America in this strategic region for local integration.

When observing the cities in border areas in South America, one can perceive a pendulous flow of people across the borders. This pendulous flow between conurbation cities is driven by trade, services, tourism, mobility and labor activities. In a single urban network, we can find cities from multiple nations, separated only by an avenue, a river or a bridge. There is a constant flow of people moving from one city to another in search of public services, shopping, work or leisure activities. In this scenario, the infrastructure of neighboring cities - health, education, tourism, transportation - must be capable of meeting its own demand and eventual surpluses. Likewise, their legislation needs to anticipate daily migration issues, especially the ones related to the labor 
mobility issues of those who live in one country and work in another. As a matter of fact, the border region situation requires a differentiated apparatus that is not always foreseen or provided for by central/national governments - subnational governments are offering solutions to these important issues, as we elaborate in the border cities initiatives (Chart 2).

Taking into consideration that there is no regularity in the definition of "border line" adopted by the South American governments in terms of its legal definition and extension, we have chosen the classification of cities in border areas, border zones and border regions along frontiers (ILADIR 2011). We have focused our study on conurbation cities in border areas because cities in areas of international borders are more likely to experience social processes of a transnational and plurinational nature. The reality of conurbation border cities demands more attention from the internationalists, since they are located in contact points between different cultures and identities, between various kinds of jurisdictions, and between local, national and international legislations. While the dynamics of border cities interact with the political and administrative limits of different countries, the reality of border cities is closely linked to the specific circumstance of being located on the border (Souza and Brites, 2017).

We have identified all the conurbation cities along the South American national borders (Chart 1; Figure 3). For this, an analysis of satellite photographs was made considering a radius of 4 kilometers of distance between urban meshes. In other words, if the urban meshes were distanced four kilometers or less apart, we considered them to be a single urban area - or a conurbation area. A total of 118 cities were identified; they were located along different borders, forming 53 conurbations in total. Of these 53 conurbations, 28 cross the borders of Brazil (BR), 20 of Argentina (AR), 13 of Paraguay (PR), 9 of Bolivia (BO), 8 of Uruguay (UR), 7 of Colombia (CO), 7 of Peru (PE), 5 of Venezuela (VE), 5 of Ecuador (EQ), 2 of Chile (CL), 1 of Guyana (GU), 1 of Suriname (SU) and 1 of French Guiana (GF).

CHART 1: CONURBATION CITIES IN SOUTH AMERICAN BORDERLINES

\begin{tabular}{|c|c|c|}
\hline Population $>1000000$ & City (Country) & Region \\
\hline 2226258 & Asunción (PR), Clorinda (AR) & La Plata \\
\hline Population $>500000$ & & Andes \\
\hline 924072 & $\begin{array}{c}\text { Foz do Iguaçú (BR), Puerto Iguazu (AR), } \\
\text { Ciudad del Este (PR) }\end{array}$ & La Plata \\
\hline 834006 & $\begin{array}{c}\text { Cúcuta (CO), V. Rosario (CO), S. Anto. } \\
\text { Táchira (VE), Ureña (VE) }\end{array}$ & Andes \\
\hline 538815 & $\begin{array}{c}\text { Posadas (AR), Candelaria (AR), Garupá } \\
\text { (AR), Encarnación (PR) }\end{array}$ & La Plata \\
\hline 531176 & Arica (CL), Tacna (PE) & La Plata \\
\hline 280681 & Concordia (AR), Salto (UR) & Andes \\
\hline 231407 & Formosa (AR), Alberdi (PR) & Lata \\
\hline 230000 & Tulcán (EQ), Ipiales (CO) & La Plata \\
\hline
\end{tabular}




\begin{tabular}{|c|c|c|}
\hline 168758 & Uruguaiana (BR), Paso de los Libres (AR) & La Plata \\
\hline 153442 & $\begin{array}{c}\text { Colón (AR), San José (AR), Paysandú } \\
(\text { UR) }\end{array}$ & La Plata \\
\hline 146506 & $\begin{array}{c}\text { Corumbá (BR), Puerto Quijarro (BO), } \\
\text { Puerto Suárez (BO) }\end{array}$ & Amazon \\
\hline 121570 & $\begin{array}{l}\text { Profesor Salvador Mazza (AR), Yacuíba } \\
\text { (BO) }\end{array}$ & Andes \\
\hline 103672 & Tabatinga (BR), Letícia (CO) & Amazon \\
\hline \multicolumn{3}{|c|}{ Population > 50000} \\
\hline 90650 & Arauca (CO), El Amparo de Apure (VE) & Andes \\
\hline 88659 & Albina (SU), Saint-Laurent du Maroni (GF) & Amazon \\
\hline 87624 & São Borja (BR), Santo Tomé (AR) & La Plata \\
\hline 82238 & Guajará Mirim (BR), Guayaramerín (BO) & Amazon \\
\hline 82227 & Zarumilla (PE), Huaquillas (EQ) & Andes \\
\hline 80500 & Casuarito (CO), Puerto Ayacucho (PE) & Andes \\
\hline 67555 & Quaraí (BR), Artigas (UR) & La Plata \\
\hline 66228 & Guaíra (BR), Salto del Guairá (PR) & La Plata \\
\hline 57309 & Arauquita (CO), La Victoria (VE) & Andes \\
\hline \multicolumn{3}{|c|}{ Population > 10000} \\
\hline 49819 & Itaqui (BR), Alvear (AR) & La Plata \\
\hline 41695 & Jaguarão (BR), Rio Branco (UR) & La Plata \\
\hline 53399 & $\begin{array}{c}\text { Barra do Quaraí (BR), Bella Unión (UR), } \\
\text { Monte Caseros (AR) }\end{array}$ & La Plata \\
\hline 44198 & Brasiléia (BR), Cobija (BO) & Amazon \\
\hline 41806 & La Quiaca (AR), Villazón (BO) & Andes \\
\hline 40636 & Bela Vista (BR), Bella Vista Norte (PR) & La Plata \\
\hline 35875 & $\begin{array}{l}\text { St. Antônio do Sudoeste (BR), Pranchita } \\
\text { (BR), S. Antonio (AR) }\end{array}$ & La Plata \\
\hline 33024 & $\begin{array}{c}\text { Coronel Sapucaia (BR), Capitán Bado } \\
\text { (PR) }\end{array}$ & La Plata \\
\hline 31030 & $\begin{array}{c}\text { Dionísio Cerqueira (BR), Barracão (BR), } \\
\text { Bernardo de Irigoyen (AR) }\end{array}$ & La Plata \\
\hline 30680 & Aguas Blancas (AR), Bermejo (BO) & Andes \\
\hline 28209 & $\begin{array}{c}\text { Oiapoque (BR), Saint-Georges-de- } \\
\text { l'Oyapock (GF) }\end{array}$ & Amazon \\
\hline 22606 & Porto Xavier (BR), San Javier (AR) & La Plata \\
\hline 21105 & Paranhos (BR), Ypehú (PR) & La Plata \\
\hline 20000 & Puerto Rico (AR), Puerto Triunfo (PR) & La Plata \\
\hline 19410 & Desaguadero (BO), Desaguadero (PE) & Andes \\
\hline 19184 & $\begin{array}{c}\text { Chuí (BR), Barra do Chuí (BR), Santa } \\
\text { Vitória do Palmar (BR), Chuy (UR), Barra } \\
\text { del Chuy (UR) }\end{array}$ & La Plata \\
\hline 17525 & Bonfim (BR), Lethem (GU) & Amazon \\
\hline 16632 & Sanga Puitã (BR), Zanja Pytã (PR) & La Plata \\
\hline 16285 & Puerto Carreno (CO), Puerto Páez (VE) & Amazon \\
\hline 15768 & Sete Quedas (BR), Pindoty Porã (PR) & La Plata \\
\hline 14890 & Copacabana (BO), Yunnguyo (PE) & Andes \\
\hline 13087 & La Tina (PE), Macará (EQ) & Andes \\
\hline \multicolumn{3}{|c|}{ Population < 10000} \\
\hline 9398 & Porto Mauá (BR), Alba Posse (AR) & La Plata \\
\hline 8485 & $\begin{array}{c}\text { Paso de la Patria (AR), Paso de Patria } \\
\text { (PR) }\end{array}$ & La Plata \\
\hline 8110 & Assis Brasil (BR), Iñapari (BO) & Amazon \\
\hline 7990 & Los Antiguos (AR), Chile Chico (CL) & Andes \\
\hline 6242 & Aceguá (BR), Acegua (UR) & La Plata \\
\hline 3000 & El Alamor (PE), Lalamor (EQ) & Andes \\
\hline 2357 & Ayabaca (PE), Zapotillo (EQ) & Andes \\
\hline
\end{tabular}

Source: the Authors, based on research data (2018).

Regarding Figure 3, it is possible to observe that the region with the largest figures in terms of population and of border conurbation cities is the region of La Plata: it has about 28 
conglomerates, with 5561920 inhabitants. The Andean region counts 16 conglomerates, with 2 129978 inhabitants. Finally, the Amazon region features 9 conglomerates, with 566082 inhabitants. The total number of inhabitants in South American conurbation border cities was of approximately 8257980 in 2017.

\section{FIGURE 3: SOUTH AMERICAN CONURBATION CITIES IN 2017 \\ SOUTH AMERICAN \\ CONURBATION CITIES 2017}

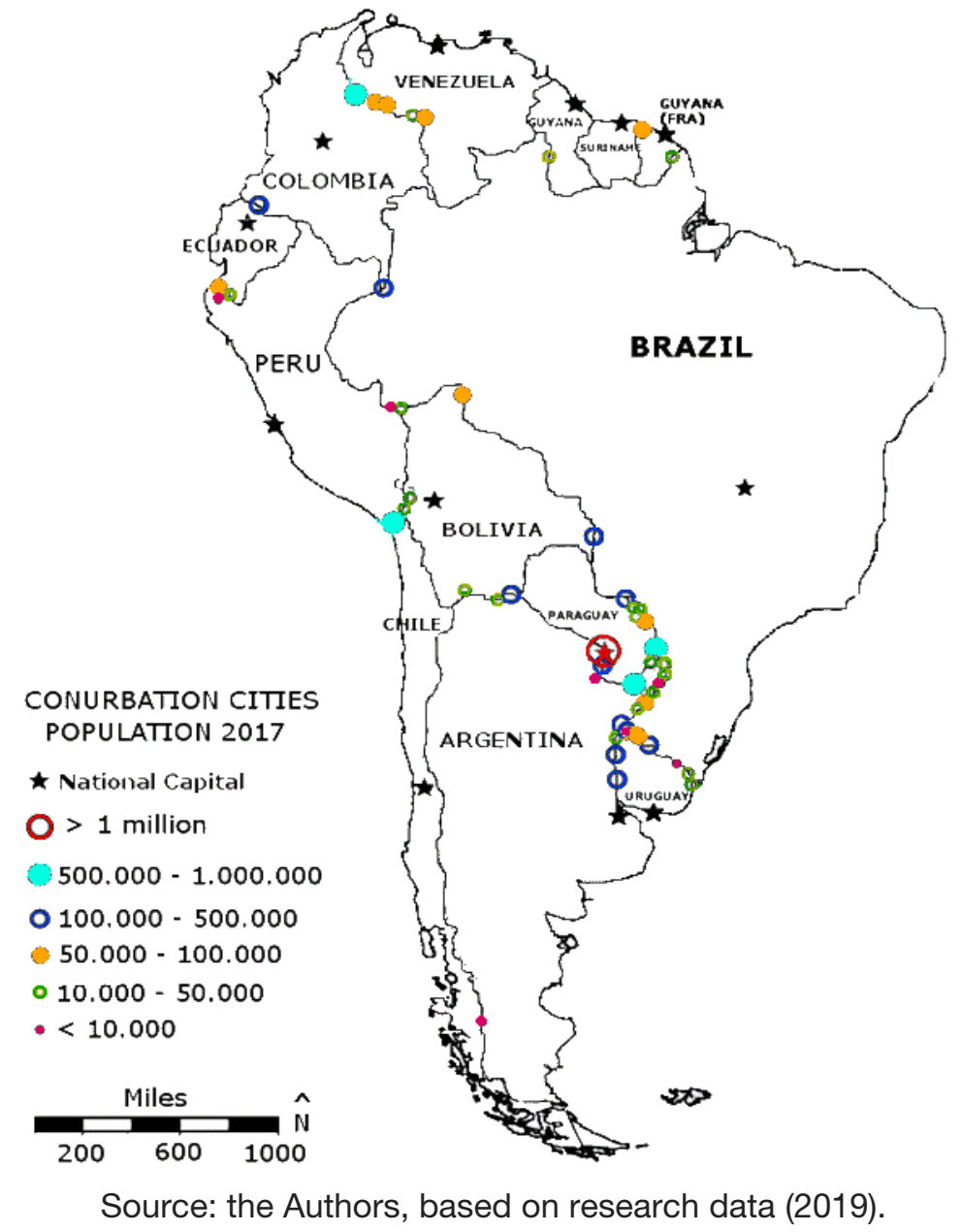

The international borders of the Amazon region are characterized not only by low population density but also by migratory flows, such as by Haitians (2010 to 2015) and Venezuelans (more recently). The Amazon and La Plata regions face challenges such as the agrarian expansion and irregular land occupation, which are both intensified by the growing populations in the area. The exploitation of natural resources and the creation of large latifúndios (large private agricultural estates) leads to deforestation, forest fires and the expulsion of local communities (especially indigenous ones). This situation can be exemplified by the brasiguaios, Brazilians who buy lands in the Paraguayan and Bolivian border areas. In this context, international agendas, such as the one relating to global warming from the Rio C40 Group, may 
even raise the awareness of small cities at the border to issues related to environmental protection. However, the dilemma of deforestation versus economic development can be seen as an obstacle to their effective participation in these processes.

A large number of cities in the regions of the La Plata and in the central-north region of the Andes are physically (by roads) and politically (by irradiated values) interconnected. La Plata is characterized by having the largest number of urban centers, as well as for being under the jurisdiction of more flexible legislations, such as the ones from Argentina and Brazil, for example (UCLG 2016). In spite of regional integration challenges, the high level of decentralization in Argentina and Brazil contributes to the external action of their cities and also encourages the internationalization of neighboring cities in Chile, Paraguay and Uruguay, among others.

One of the great challenges for cities in the La Plata region is the bureaucratic and legal obstacles to transit and capital flow, which prevent, for example, ambulances and other governmental support services from crossing borders. This illustrates how difficult human integration is. Moreover, these issues may be aggravated by security concerns. For example, the efforts from local mayors to monitor crimes in border regions, especially concerning the circulation of vehicles, evidence legal conflicts in joint police actions of different nationalities. The lack - and sometimes the complete absence - of actions, policies and planning from and among national governments is very common in the daily routine of the cities in the three regions observed in this research. The Brazilian government itself recognizes this dearth in a document produced for the presentation of the Programa de Desenvolvimento da Faixa de Fronteira (Border Area Development Program, PDFF):

Even though it [PDFF] is strategic for South American integration, since it is bordered by ten countries, corresponds to approximately $27 \%$ of the national territory (11 states and 588 municipalities) and concentrates about 10 million inhabitants, the border area is historically abandoned by the State and is marked by the difficulty of access to goods and public services, lack of social cohesion, non-observance of citizenship and by problems peculiar to border regions. (Brasil 2009,6 , our translation)

Considering the low or insufficient participation of national governments in the development processes and in ensuring rights to local communities, we stress the relevance of studying local cities and their actions in border areas. Based on Egler's research (2012) using the concept of nodality, it is possible to observe a layout of physical connectivity and influence among cities in South America. Although the author only studies cities with more than 100,000 inhabitants (Figure 4), and in our research most of the border cities have a population smaller than this number, there is an important contribution in terms of the visual understanding of the axes of irradiation and subordination among cities. 
FIGURE 4: NODALITY AND IRRADIATION AMONG CITIES IN SOUTH AMERICA

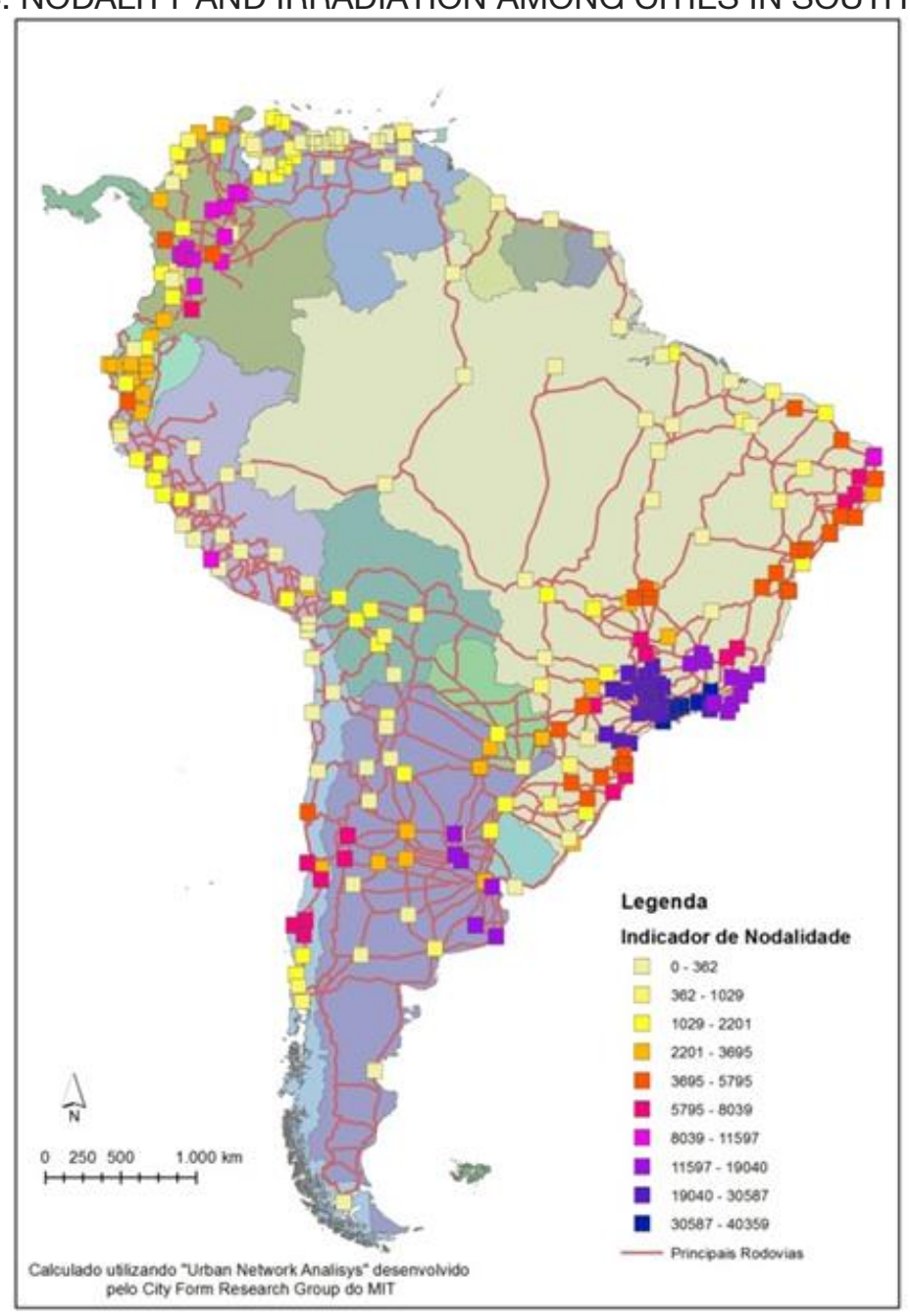

Source: Egler (2012).

Based on Egler's studies, it is possible to affirm that the majority of the conurbation border cities are influenced by other larger South American cities (São Paulo, Rio de Janeiro, Buenos Aires, Belo Horizonte, Bogotá, Santiago de Chile, Recife e Lima), a realistation that would ultimately influence the creation of the Mercocities Network by following the examples given by these major cities of the network (Mercher and Ferreira 2015). The establishment of South American city networks was spearheaded by central capitals and global cities such as Bogotá, Buenos Aires, Curitiba, Lima, Montevideo, Quito, Rio de Janeiro and São Paulo.

As we mentioned before, it is possible to identify in South America at least 14 official city networks. We have considered only the Mercocities Network for our documentary analysis. However, one can not diminish its importance based on the fact that it was our only tangible option: it is the largest network in terms of number of members and concentrates the largest number of cities in border regions. To sum up, it is the best option for a broader analysis of South America. The Mercocities Network does not include solely the subnational governments from countries that are members of MERCOSUR. Created with the aim of achieving a greater 
participation in integration processes within MERCOSUR, it currently has cities in ten of the twelve South American countries, crisscrossing the borders within the bloc. In addition, the Mercocities Network established a Border Integration Workgroup in 2013 based on a number of previous meetings and events that discussed development and integration in border areas, such as the Merco-regions.

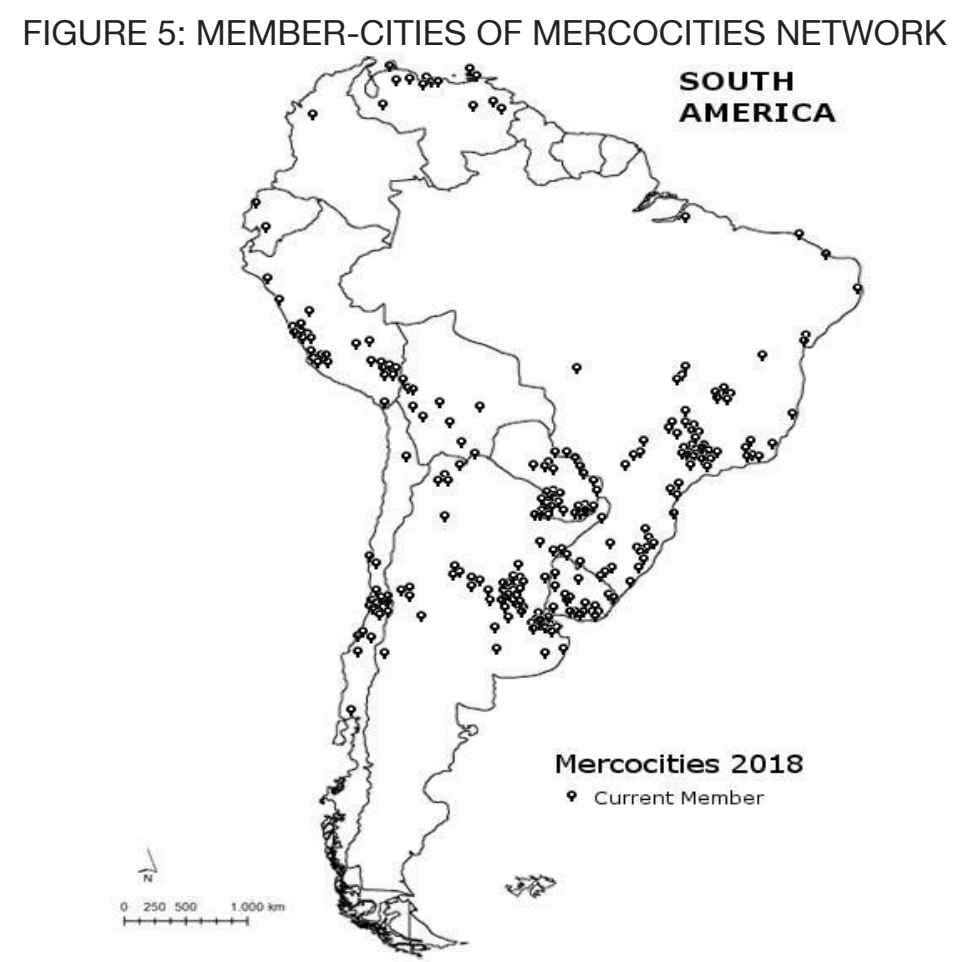

Source: Adapted by the authors, from Mercocities (2018a).

A total of 340 South American cities are part of this network (Figure 5). Eighteen are located in border regions: Concordia and Posadas (Argentina); Santa Vitória do Palmar, Paranhos, Coronel Sapucaia, Bela Vista, Barra do Quaraí, Guaíra and Foz do Iguaçu (Brazil); Arica (Chile); Asunción, Ypehú, Bella Vista Norte, Salto del Guairá, Pedro Juan Caballero (Paraguay); Paysandú, Rivera and Salto (Uruguay). Although Bolivia, Colombia, Ecuador, Peru and Venezuela have some border cities, they do not participate in big networks such as Mercocities or REDCISUR. Our research encompasses 5294430 inhabitants:

CHART 2: SOUTH AMERICAN CONURBATION CITIES THAT ARE MEMBERS OF THE MERCOCITIES NETWORK

\begin{tabular}{|c|c|c|}
\hline Region & Conurbation cities & Number of Inhabitants \\
\hline \multirow{4}{*}{ La Plata } & Concordia (AR) - Salto (UR) & 280681 \\
\cline { 2 - 3 } & Posadas (AR), Candelaria (AR), Garupá (AR) / Encarnación & 538815 \\
\cline { 2 - 3 } & Costanera (PR) & 2226258 \\
\cline { 2 - 3 } & Assunción (PR) - Clorinda (AR) & 21105 \\
\cline { 2 - 3 } & Ype-hú (PR) - Paranhos (BR) & 40636 \\
\cline { 2 - 3 } & Bella Vista Norte (PR) - Bela Vista (BR) & 205434 \\
\cline { 2 - 3 }
\end{tabular}




\begin{tabular}{|c|c|c|}
\hline \multirow{4}{*}{} & Paysandu (UR) - Colón (AR), San José (AR) & 153442 \\
\cline { 2 - 3 } & Rivera (UR) - Santana de Livramento (BR) & 186820 \\
\cline { 2 - 3 } & Chuí (BR) / Chuy (UR); Barra do Chuí (Sta. Vitória do Palmar, BR) / \\
& Barra del Chuy & 19184 \\
\cline { 2 - 3 } & Coronel Sapucaia (BR) / Capitán Bado (PR) & 33024 \\
\cline { 2 - 3 } & Guaíra (BR) / Salto del Guairá (PR) & 66228 \\
\cline { 2 - 3 } & Foz do Iguaçú (BR) / Puerto lguazu (AR) / Cidad del Este \\
& (Metropolitan Region, PR) & 672 \\
\cline { 2 - 3 } & Quaraí (BR) / Artigas (UR) & 531176 \\
\hline Andean & Arica (CH) - Tacna (PE) & 0 \\
\hline Amazon & - & 5294430 \\
\hline
\end{tabular}

Source: the Authors, based on Mercocities (2018).

To network or integrate with cities and regions that experience similar problems to yours is a way of strengthening one's position, especially if the majority of those cities (except for Asunción, PY) are located far from political and financial urban centers, thus being subordinated to public policies emanating from these centers (nodal points). Border cities receive smaller loans from central governments and have fewer sources of revenue.

The cross-border cooperation led by South American cities compensates for the lack of action from national governments and is a key mechanism for fueling a convergent economy and social development in these regions, while creating new autonomous growth opportunities for each region. In addition, the integration of actors, agendas, policies and financial means generates a "flexible specialization" and offers incentives and stimulates the production of goods and the seeking of answers to common regional problems. It also prevents a single country from assuming costs (political or economic) it cannot afford single-handedly, avoiding conflicts, building consensus and governance strategies and, finally, allowing local institutions and actors to acquire new technical, financial and political capacities (Oddone et al. 2016, 7, 35).

In this section, we have listed the border areas in South America, the cities that integrate these areas and the ones that are part of a network. In the next section, our focus will be on the analysis of concrete integration actions undertaken by these cities that were identified in our data collection.

\section{MERCOCITIES NETWORK: INITIATIVES IN MULTILEVEL GOVERNANCE}

The 18 conurbation border cities that are participating in the Mercocities Network have broad policy agendas. Demands for security, development, social rights and visibility are featured in the sets of data from the 16 workgroups that have taken place since 1995. The Mercocities Network, has made joint actions with national governments, universities and other social agents 
possible. This section highlights actions oriented towards the integration, valorization and strengthening of the autonomy of these cities.

Some initiatives identified in the scope of Mercocities are: policies for young people in situations of vulnerability (Paysandu and Rivera, Youth Thematic Unit); the Bilateral Program of Technical Assistance in Governability (Barra do Quaraí, Thematic Unit of Strategic Planning); integrated tourism projects (Foz do Iguaçu, Tourism Thematic Unit); joint city Master plans (Pedro Juan Caballero and Ponta Porã, Bella Vista Norte and Bela Vista, Thematic Unit of Local Economic Development); among others.

Furthermore, initiatives in the social, development, tourism, culture, environment and urban sectors are also included in the Mercocities actions. We have developed a framework that not only groups together the main actions within the Network but also presents them in an autonomous way.

\section{CHART 3: INITIATIVES FROM BORDER CITIES}

\begin{tabular}{|c|c|}
\hline Initiatives & Examples \\
\hline Social & $\begin{array}{l}\text { 1. Coronel Sapucaia: Workshop “Educação Ambiental da Região da Fronteira Brasil-Paraguai” } \\
\text { [Environmental Education of Brazil-Paraguay Border Region - BR / PR] } \\
\text { 2. Coronel Sapucaia: Programa Escolas Interculturais de Fronteira [Intercultural Border } \\
\text { Schools Program - BR] } \\
\text { 3. Paysandu: Escola Agraria de Paysandu/Escuela de Alternancia Guaviyu - binacional } \\
\text { [Agricultural School of Paysandu - UR / AR (MERCOCIDADES, 2018j)] } \\
\text { 4. Paysandu e Rivera: políticas conjuntas para jovens em situação de vulnerabilidade [Joint } \\
\text { project policies for vulnerable young people - UR / AR] (MERCOCIDADES, 2018n) } \\
\text { 5. Clorinda, Encarnacion, Posadas: acordo sobre políticas migratórias [Agreement on } \\
\text { migration policies - AR / PR] } \\
\text { 6. Arica e Tacna: convênio de integração universitária através da Universidade do } \\
\text { Tarapacá/CH [Covenant on academic integration through Tarapaca University / PE - CH] } \\
\text { 7. Pedro Juan Caballero e Ponta Porã: Parlamento Binacional [Binational Parliament, PARLIN / } \\
\text { PR / BR] } \\
\text { 8. Bella Vista Norte e Bela Vista: Parlamento Binacional [Binational Parliament, PARLIN / PR / } \\
\text { BR] } \\
\text { 9. Pedro Juan Caballero e Ponta Porã: Escola Intercultural Bilíngue de Fronteira [Intercultural } \\
\text { Bilingual Border School / PR / BR] }\end{array}$ \\
\hline Development & $\begin{array}{l}\text { 1. Coronel Sapucaia: Programa Fomenta Fronteiras - [Border Promotion Project / BR] } \\
\text { 2. Foz do Iguaçu: Comitê de Fronteira Brasil - Argentina [Border Committee BR - AR] } \\
\text { 3. Foz do Iguaçu: Movimento pela tomada da Carteira Fronteiriça [Movement for the Border } \\
\text { Identification Card / AR / BR / PR] }\end{array}$ \\
\hline
\end{tabular}




\begin{tabular}{|c|c|}
\hline & $\begin{array}{l}\text { 4. Concordia e Salto: agenda comum de cooperação internacional [Common agenda for } \\
\text { international cooperation AR / UR] (MERCOCIDADES, 2018e) } \\
\text { 5. Barra do Quaraí: Programa Bilateral de Assistências Técnicas em Governabilidade [Bilateral } \\
\text { programme of technical assistance in governability - BR] (MERCOCIDADES, 2018o) } \\
\text { 6. Foz do Iguaçu: Realização do Seminário Internacional de Regiões de Fronteiras [Execution } \\
\text { of the International Seminar on Border Regions - BR] (MERCOCIDADES, 2018m) } \\
\text { 7. Posadas, Garupa, Candelaria, Encarnación: formação de um conglomerado urbano } \\
\text { binacional [Formation of a binational urban conglomerate / AR / PR] } \\
\text { 8. Posadas - Encarnación: Comitê de Integração [Integration Committee AR / PR] } \\
\text { 9. Asunción - Clorinda: Projeto de Optimización del nodo Clorinda-Asunción [Optimization } \\
\text { Project of Urban Node Clorinda-Asunción / PR / AR] } \\
\text { 10. Arica e Tacna: integração de redes de energia elétrica [Integration of electrical power grid / } \\
\text { CH / PE] } \\
\text { 11. Pedro Juan Caballero e Ponta Porã: revitalização da linha internacional de fronteira } \\
\text { [Revitalization of the international border line / PR / BR] } \\
\text { 12. Pedro Juan Caballero e Ponta Porã: criação de um mercado popular [Creation of a popular } \\
\text { market / PR / BR] }\end{array}$ \\
\hline Tourism & $\begin{array}{l}\text { 1. Foz do Iguaçu: Reunião organizada pelo COMTUR promoveu a discussão sobre os } \\
\text { problemas do transporte na fronteira com o Paraguai [Meeting organized by COMTUR } \\
\text { promoted the discussion on the problems of mobility/road transportation on the border with } \\
\text { Paraguay / BR / PR] } \\
\text { 2. Foz do Iguaçu: Projeto Roteiros Integrados de Turismo [Project of Integrated Tourism } \\
\text { Routes / BR / AR / UR] (MERCOCIDADES, 2018q) } \\
\text { 3. Rivera e Paysandu: integrantes do grupo de cidades participantes da rota TCHÊ [Members } \\
\text { of city group of Route TCHÊ / AR / UR] (MERCOCIDADES, 2018q) }\end{array}$ \\
\hline Culture & $\begin{array}{l}\text { 1. Arica:: Realização de um encontro latinoamericano de cueca [Latin-american meeting of } \\
\text { "cueca" as a folk dance/ CH] (MERCOCIDADES, 2018f) }\end{array}$ \\
\hline Environment & $\begin{array}{l}\text { 1. Foz do Iguaçu, Puerto Iguazu e Ciudad del Este: programa de desenvolvimento sustentável } \\
\text { conjunto [Project "joint sustainable development" / BR / AR / PR] } \\
\text { 2. Concordia e Salto: políticas ambientais de proteção ao aquífero guarani [Environmental } \\
\text { policies to protect the Guarani Aquifer / AR / UR] } \\
\text { 3. Rivera e Santana do Livramento: políticas ambientais de proteção ao aquífero guarani } \\
\text { [Environmental policies to protect the Guarani Aquifer / UR / BR] } \\
\text { 4. Ponta Porã e Pedro Juan Caballero: políticas ambientais de proteção ao aquífero guarani } \\
\text { [Environmental policies to protect the Guarani Aquifer / PR / BR] } \\
\text { 5. Pedro Juan Caballero e Ponta Porã: gestão integrada de rios [Integrated river management } \\
\text { / PR / BR] }\end{array}$ \\
\hline Urbanism & $\begin{array}{l}\text { 1. Pedro Juan Caballero e Ponta Porã: plano diretor conjunto [Joint urban planning / PR / BR] } \\
\text { (MERCOCIDADES, 2018g) } \\
\text { 2. Bella Vista Norte e Bela Vista: plano diretor conjunto [Joint urban planning / PR / BR] } \\
\text { (MERCOCIDADES, 2018g) }\end{array}$ \\
\hline
\end{tabular}




\begin{tabular}{|l|l|}
\hline & $\begin{array}{l}\text { 3. Posadas: planejamento urbano estratégico, prevendo integração com cidades fronteiriças } \\
\text { [Strategic urban planning, integration with border cities / AR] (MERCOCIDADES, 20180) }\end{array}$ \\
$\begin{array}{l}\text { 4. Posadas: “Integración Urbana y Calidad Ambiental: Programa movilidad, transporte e } \\
\text { articulación territorial” [Urban Integration and Environmental Quality: Mobility, transport and } \\
\text { territorial articulation program / AR] }\end{array}$ \\
$\begin{array}{l}\text { 5. Santana do Livramento e Rivera: planejamento urbano integrado prevê a integração } \\
\text { fronteiriça [Integrated urban planning providing border integration / BR/ UR] }\end{array}$ \\
\hline Security & $\begin{array}{l}\text { 1. Foz do Iguaçu: Seminário sobre a prevenção de crimes transfronteiriços [Seminar on the } \\
\text { prevention of cross-border crime / BR] }\end{array}$ \\
\hline
\end{tabular}

Source: Authors based on MERCOCIDADES (2018a), official data from governments (2018) and on Torrecilha (2013, 2014), Brites (2014), Irigaray et al. (2016).

Some specificities in the integration initiatives led by conurbation border cities were perceived. One of them is the preoccupation with territorial ordering, which is indicated in the joint urban planning initiatives from the cities of Pedro Juan Caballero (PR) and Ponta Porã (BR), Bella Vista Norte (PR) and Bela Vista (BR), Santana de Livramento (BR) and Rivera (UR). In other words, cities seek to solve problems that arise from disordered urban growth by organizing themselves, aiming to minimize their effects. This disordered growth is common to conurbation cities and is aggravated by the situation of the borders in South America. The same goes for environmental policies, where we can observe the articulation of cities around sensitive issues, such as the Guarani Aquifer. Another interesting example is the existence of binational municipal forums to discuss political, socio-cultural and economic issues (PARLIN - Pedro Juan Caballero (PR) and Ponta Porã (BR), Bella Vista Norte (PR) and Bela Vista (BR)). These spaces are integrative forums created to discuss and advise the population on everyday issues, inspired by the European Parliament and the Andean Community Parliament.

Regarding the initiatives developed by conurbation cities in border areas from the perspective of multilevel governance, universities can be considered a relevant actor, alongside public institutions, private initiatives and civil society. Universities played a decisive role, for example: in the development of the joint Master plans of Ponta Porã (BR) and Pedro Juan Caballero (PR) (Federal University of Mato Grosso do Sul / UFMS-BR); in the integration of universities in the cities of Arica $(\mathrm{CH})$ and Tacna (PE) (University of Tarapaca / $\mathrm{CH}$ ); in the monitoring of environmental policies related to the Guarani aquifer (UFMS-BR and Federal University of Rio Grande do Sul / UFRGS-BR); and also in the creation of the Border Integration Workgroup within the Mercocities Network (Ritter dos Reis University Center / Laureate International Universities network-BR). Universities bring together individuals that are fundamental for the formation of knowledge on policies and contribute to generating ideas and alternatives that influence decision makers in the formulation of public policies (Kingdon 2003). 
The most relevant institutional achievement that we have identified within the Mercocities Network was the creation of the Border Integration Workgroup (UTIF), in 2013. The UTIF made it possible to operationalize border cities' agendas within the Mercocities Network. Following several thematic seminars about regions and borders held by its members, the UTIF became a space of dialogue and demand for cities in border areas. Asunción (Paraguay / PR), Uruguaiana, Itaqui and Santa Vitória do Palmar (Brazil / BR) also contributed to its creation (Mercocidades 2018m). The UTIF created an annual work plan, focusing on the valorization of the border culture, the search for local potentialities and how to overcome common challenges (bureaucracies, public services, integration issues, crime, and so on).

The creation of the UTIF, helped expand the debate on border regions beyond security issues and the reaction to specific actions requested by national governments. The UTIF reinforced the discussion about the challenges and opportunities of transnational processes experienced by outlying cities, which gave a voice to communities and local governments in border regions. This is the reason for researching cities in border areas specifically, and their connections within Mercocities. For example, in the 2016 Work Plan of the UTIF (Mercocidades 2018m), the demanded actions were: i) articulation between governments, public and private institutions (trade associations, service clubs, NGOs, state and national government bodies); ii) joint public policies, such as health, education, environment, security and border trade; iii) training in public management and the financing of projects, consortia and agreements between border municipalities and Merco-regions; iv) articulation of local governments responsible for border regions within the institutional space that Mercocities Network has in the FCCR through the Border Integration Workgroup (UTIF), with other government agencies, the civil society and with universities; v) to go beyond academic research on the understanding of the complex relations involving border areas, drawing universities' attention to the need for discussion on concepts about borders and aiming at improvements in the socio-territorial organization and in the construction of citizenship in border cities and regions, as well as at strengthening Merco-regions as a whole.

With the creation of the UTIF, the cities involved broadened the debate on border regions beyond security issues and specific actions from their national governments, to consider the broader challenges and opportunities of transnational processes as well (Mercocidades 2018m). This process gave voice to local governments and communities in border regions, in addition to the multilevel gains of cooperation with regional integration processes.

It is important to remember that the creation of the FCCR at MERCOSUR in 2004 was due to the demand of the Mercocities for more institutional space for the actions of local governments within MERCOSUR: "The creation of this Consultative Forum has been a permanent vindication 
since the very birth of Mercocities as an area to institutionalize the participation of the cities at the highest level of the integration process" (Mercocidades 2018a, our translation). However, it was only in 2015 that border issues did gain prominence in the regional agenda of local and national governments.

Whereas the UTIF was established within the Mercocities Network, cities of border regions, represented by Cerro Largo (UR), were able to take the lead of the FCCR and propose the creation of the Merco-regions. As a city agenda, the Merco-regions became a field of work within the FCCR, bringing together for dialogue and for action local governments, represented by Mercocities and their members, and national governments, represented by MERCOSUR. When the Uruguayan mayor of Cerro Largo, Sergio Botana, assumed the presidency of the FCCR in 2015, he emphasized that the Merco-regions:

[...] are an initiative to integrate citizens who live mainly at the borders. The objective of the Merco-regions is that borders cease being a limitation to become a space that generates opportunities [...] [under a structure] that eliminates situations such as having health services on one side and doctors on the other, where people are the ones standing in-between. (Todo El Campo 2015, our translation).

The aim is to overcome national boundaries as limits and to value joint action and integration, as it recognizes plurinational communities as part of a same society. According to the mayor of Cerro Largo, the demands in the Merco-regions are to:

Take advantage of bilingual education on both sides of the border, ceasing to dispute students and looking for cooperation agreements. Do not duplicate services but share them, as in the case of energy, communications or drinking water. I propose the possibility of sharing basic sanitation services and the final disposal of waste. [...] Work on everything related to the environment, where only governments close to the people can stop the big corporations working with the big countries, because it is difficult for them [national governments] to put a stop to the indiscriminate advance of those who destroy the planet. (Ibidem 2015, our translation).

Still on the importance of subnational governments, the mayor of Cerro Largo, and current president of the FCCR, stated that "it is important to talk less about sovereignty in border areas and more about harmony", criticizing national agendas, which remain distant from the local reality when dealing with integration processes. Besides the Mercocities Network and its UTIF, border cities and regions gained another institutional voice within the regional integration process in the Consultative Forum of the MERCOSUR. 


\section{FINAL CONSIDERATIONS}

The analysis of the data collected in our research from a multilevel governance perspective allows us to reach a number of important conclusions. In spite of the peculiarities of the border regions, which in South America can be intensified by geographic, demographic, economic and political aspects, we have identified cooperation activities among subnational governments. These network actions aim to broaden, within the institutional domain, the voice of local communities and to overcome historical obstacles to the development of border regions.

The main economic and demographic cities of South America are geographically far from the borders, except for Asunción/PR. Sometimes, nodal distance generates bureaucracies that transform national states themselves in constraints for border integration processes regarding issues such as sovereignty and control of transnational processes (such as trafficking and migration). Border securitization projects, such as Operation Ágata (BR), are a consequence of the permeability of these regions and the prevalence of criminal activity such as trafficking in drugs, animals and weapons, as well as smuggled goods. The problem of border security arises not only from physical distance, but also from the institutional distance between these regions and the State.

This institutional gap stemming from the lack of action of central governments creates a window of opportunity for the action of subnational units. According to our data collection, it is possible to observe that cities in border areas, zones and regions have been increasingly mobilized in cooperation networks in recent years. In this context, the Mercocities Network plays a key role, since it is the only institution that prioritizes regional integration while maintaining institutional incentives, such as the UTIF. The other networks are also very important for the strengthening of cities in the regional and international scenario, but often their agendas revolve either around national capital cities, as in the South American Cities Network (REDCISUR), or around a very restricted action, such as the Red de Ciudades Suramericanas (Andean Network of Cities, RAC), facing the Andes.

Another observed aspect is: after a few years of having their agendas subordinated to large cities, border cities began to insert their own agendas in the debate. By using these network-articulated spaces, especially in the case of the Mercocities Network, border cities can expose their demands and seek cooperation with other local and national governments. This is often done through institutional channels, such as: Mercocities Network (1995), whose recognition of the importance of the border agenda resulted in the creation of the UTIF (2013); and GTIF (2015), a workgroup from the FCCR (MERCOSUR) for border integration with the Merco-regions agenda. For this reason, we notice that MERCOSUR is a facilitator and investor in 
border region integration processes, playing an important role by bringing together various agents.

In other words, network actions lead to relevant institutional results by establishing privileged spaces for the promotion and dissemination of autonomous practices and public policies of the member-cities and allowing for cooperation and political gains in a scenario of regional integration. This dynamic favors actions of multilevel governance at different territorial levels: i) local, national, regional and international; ii) functional/legislative, executive and judicial; iii) by areas of specialization, by topic, by sector policy, and so on; iv) with business, with nongovernmental organizations, with universities and epistemic communities and with the civil society. It can be inferred that articulation in city networks, such as Mercocities, contributes to an increase in social participation, since it allows different social agents to participate in regional governance, inserting themes and local demands in national agendas.

The Mercocities Network is one of the first institutionalized spaces for the representation, the proposing of demands and the formulation of specific policies of South American border communities that interacts directly with national governments and international organizations. It seeks to value border culture, favoring processes of integration between peoples and bringing together nations. It acts as a space for policies diffusion and for dialogue between cities in border regions and initiatives in various fields - from educational, cultural, infrastructural and so on aiming at integration. Possibly because they have space for their demands in other workgroups of the Mercocities Network, border cities, together with other agents of society - like universities created the Border Integration Workgroup, which established agendas that correspond to the realities, challenges and possibilities of their local governments and communities.

Just to remember, both the UTIF (Mercocities Network) and the GTIF (MERCOSUR) are united to discuss border issues beyond the regional integration bloc itself, as in the cases of the border cities between Chile and Peru. For this reason, we consider that border cities are improving the regional integration processes in South America by multilevel governance beyond MERCOSUR national borderlines. As the main result we can consider the existence of multilevel governance among border cities - by Mercocities Network, as an institution; the national governments and their intranational institutions; and by MERCOSUR to solve common challenges in our contemporary borderlines.

* Artigo recebido em 08 de novembreo de 2019, aprovado em 02 de dezembro de 2019. 


\section{REFERENCES}

Acuerdo de cooperación entre la red andina de ciudades y la red de mercociudades, 2007. Available $<$ http://portal.mercociudades.net/sites/portal.mercociudades.net/files/archivos/documentos/Conv eniosAcuerdos/ConvenioRAC-MERCOCIUDADES.pdf>. Retrieved on 23 Mar 2018.

Associação Brasileira de Municípios (ABM). Seminário Internacional de Regiões de Fronteiras tem início dia 29 de maio, 2018. Available at <http://www.abm.org.br/seminario-internacional-deregioes-de-fronteiras-tem-inicio-dia-29-de-maio/>. Retrieved on 22 Feb 2018.

Brasil. Cartilha do Programa de Desenvolvimento da Faixa de Fronteira, 2009. Available at $<$ http://www.integracao.gov.br/c/document_library/get_file?uuid=e5ba704f-5000-43df-bc8e-

01df0055e632\&groupld=10157>. Retrieved on 23 Mar 2018.

Brites, Walter. "Políticas públicas supra-estatales y gobernabilidad urbana internacional. El caso de las ciudades de Posadas, Argentina y Encarnación, Paraguay". In: Periferias, Fronteras y Diálogos. Actas del XIII Congreso de Antropología de la Federación de Asociaciones de Antropología del Estado Español Tarragona, 2-5 de septiembre de 2014.

Carneiro Filho, Camilo Pereira. Processos de transfronteirização na bacia do Prata: a tríplice fronteira Brasil-Argentina-Paraguai. Tese de Doutorado. UFRGS, 2013.

Castello, lara Regina. Hausen, Ênio costa. Lehnen, Arno Carlos. Schäfer, Neiva Otero. Silva, Pedro Câncio. Souza, Suzana Bleil. Práticas de integração nas fronteiras: temas para o Mercosul. Porto alegre: UFRGS/Goethe Institut/ICBA, 1995.

Czempiel, Ernst-Otto; Rosenau, J. N. Governança sem governo: ordem e transformação na política mundial. Brasília: Editora UNB, 2000.

Confederaçao Nacional Dos Muicípios(CNM). CNM apoia Seminário Internacional de Regiões de Fronteiras, 2018. Available at <http://www.cnm.org.br/comunicacao/noticias/cnm-apoiaseminário-internacional-de-regiões-de-fronteiras>. Retrieved on 22 Feb 2018.

Comunidad Andina. La integración andina y el desarrollo local y regional, 2018. Available at <http://www.care.pe/pdfs/GOBER_Fortalece/documentos/Integracion\%20Andina\%20CAN.pdf>. Retrieved on 23 Mar 2018.

Egler, Claudio. Nodalidade e rede de cidades na América do Sul. Confins, 2012. Available at $<$ http://confins.revues.org/7878>. Retrieved on 21 Oct 2017.

Iladir- Instituto Latinoamericano de Derecho Internacional y Relaciones Internacionales. Diplomacia y cooperación descentralizada: un instrumento para el desarrollo y la gobernabilidad de las regiones. $2011 . \quad$ Available at <http://www.paradiplomacia.org/upload/downloads/cf109a23fa83f3e6f443c2532686b4b5diplom aciaycooperaci\%C3\%B3ndescentralizada.pdf>. Retrieved on 23 Mar 2018.

Irigaray, Michele; Martins, Evilhane; Ritter, Giane. Sistema aquífero guarani: desafios para uma gestão integrada e sustentável. $5^{\circ}$ Fórum Internacional ECOINOVAR, $1^{\text {a }}$ Conferência Internacional de Sustentabilidade e Inovação, Santa Maria/RS - 9 a 12 de Agosto de 2016.

Hooghe, Liesbet; Marks, Gary. Unraveling the central state, but how? Types of multi-level governance. American political science review, 97 (2): 233-243, 2003. 
Kingdon, John. Agendas, alternatives, and public policies. Boston: Little, Brown, 2003.

Mackinder, Halford John. Britain and the British Seas. London: William Heinemann, 1902.

Mariano, Marcelo P.; Mariano, Karina P. "Governos subnacionais e integração regional: considerações teóricas". Em Wanderley, Luiz Eduardo; Vigevani, Tullo (orgs.). Governos subnacionais e sociedade civil: integração regional e Mercosul. São Paulo: EDUC; Fundação Editora da Unesp; Fapesp, pp. 131 a 160, 2005.

Mercher, Leonardo; Ferreira, Ana Paula Lopes. Mercocidades: cidades globais como agenteschave na agenda da cooperação descentralizada. Belo Horizonte: ABRI, 2015. Available at $<$ http://www.encontronacional2015.abri.org.br/site/anaiscomplementares?AREA=17\#L>.

Retrieved on 22 Feb 2018.

Ministério da Justiça. Seminário internacional discute os desafios das regiões de fronteira. Available at <http://www.justica.gov.br/news/seminario-internacional-discute-os-desafios-dasregioes-de-fronteira>. Retrieved on 22 Feb 2018.

Prefeitura Municipal de Coronel Sapucaia. SEMEC de Cel. Sapucaia participou workshop sobre "Educação Ambiental da Região da Fronteira Brasil-Paraguai". Available at $<$ http://coronelsapucaia.ms.gov.br/noticiasView/588_SEMEC-de-Cel.-Sapucaia-participouworkshop-sobre-“Educacao-Ambiental-da-Regiao-da-Fronteira-Brasil-Paraguai”,-em-PontaP.html>. Retrieved on 22 Feb 2018.

Prefeitura Municipal De Coronel Sapucaia. "A Secretaria Municipal de Educação na formação dos professores". 2018. Available at <http://coronelsapucaia.ms.gov.br/noticiasView/690_ASecretaria-Municipal-de-Educacao-na-formacao-dos-professores-.html>. Retrieved on 22 Feb 2018.

Prefeitura Municipal de foz do Iguaçu. Prevenção de crimes transfronteiriços: Prefeito anuncia em seminário licitação de 130 faixas monitoradas que vão registrar placas dos veículos. 2018. Available at <http://www.pmfi.pr.gov.br/noticia/?idNoticia=32523>. Retrieved on 22 Feb 2018.

Prefeitura Municipal de foz de Iguaçu. Comitê de Fronteira Brasil - Argentina: Reunião do Comitê de Integração Fronteiriça Foz do Iguaçu - Puerto Iguazú trata de temas de interesse da região. Available at <http://www.pmfi.pr.gov.br/noticia/?idNoticia=32425>. Retrieved on 22 Feb 2018.

Prefeitura Municipal de foz de Iguaçu. Município quer retomar carteira fronteiriça: documento seria destinado aos moradores da região de fronteira. Available at <http://www.pmfi.pr.gov.br/noticia/?idNoticia=31242>. Retrieved on 22 Feb 2018.

Red Andina de ciudades (RAC). Memórias. Bogotá. 2004. Available at $<$ http://www.sdp.gov.co/portal/page/portal/PortalSDP/SeguimientoPoliticas/politicalntegracionRe gional/Documentos/PA002-3RedAndinaCiudades-2004.pdf>. Retrieved on 23 Mar 2018

Rede Mercocidades. Documentos gerais. (documents) Available at <http://www.mercociudades.org/pt-br>. Retrieved on 28 mar de 2018a.

Rede Mercocidades. Documentos da Unidade Temática Ambiente e Desenvolvimento. Available at $<\mathrm{http}: / /$ www.mercociudades.org/pt-br/node/2118>. Retrieved on 28 Mar de 2018b.

Rede Mercodidades. Documentos da Unidade Temática Autonomia, Gestão e Participação. Available at <http://www.mercociudades.org/pt-br/node/2182>. Retrieved on 28 Mar de 2018c. 
Rede Mercocidades. Documentos da Unidade Temática Ciência e Tecnologia. Available at <http://www.mercociudades.org/pt-br/node/2115>. Retrieved on 28 Mar de 2018d.

Rede Mercocidades. Documentos da Unidade Temática Cooperação Internacional. Available at <http://www.mercociudades.org/pt-br/node/2184>. Retrieved on 28 mar de 2018e.

Rede Mercocidades. Documentos da Unidade Temática Cultura. Available at <http://www.mercociudades.org/pt-br/node/2119>. Retrieved on 28 Mar de $2018 \mathrm{f}$.

Rede Mercocidades. Documentos da Unidade Temática Desenvolvimento Econômico Local. Available at <http://www.mercociudades.org/pt-br/node/2120>. Retrieved on $28 \mathrm{Mar}$ de $2018 \mathrm{~g}$.

Rede Mercocidades. Documentos da Unidade Temática Desenvolvimento Social. Available at <http://www.mercociudades.org/pt-br/node/2116>. Retrieved on 28 Mar de 2018h.

Rede Mercocidades. Documentos da Unidade Temática Desenvolvimento Urbano. Available at <http://www.mercociudades.org/pt-br/node/2121>. Retrieved on 28 Mar de 2018i.

Rede Mercocidades. Documentos da Unidade Temática Educação. Available at <http://www.mercociudades.org/pt-br/node/2127>. Retrieved on 28 Mar de 2018j.

Rede Mercocidades. Documentos da Unidade Temática Gênero e Município. Available at <http://www.mercociudades.org/pt-br/node/2126>. Retrieved on 28 Mar de 2018k.

Rede Mercocidades. Documentos da Unidade Temática Grupo de Comunicação. Available at <http://www.mercociudades.org/node/5170>. Retrieved on 28 Mar de 2018l.

Rede Mercocidades. Documentos da Unidade Temática Integração Fronteiriça. Available at $<$ http://www.mercociudades.org/node/5584>. Retrieved on 28 Mar de 2018m.

Rede Mercocidades. Documentos da Unidade Temática Juventudes. Available at <http://www.mercociudades.org/node/2117>. Retrieved on 28 Mar de 2018n.

Rede Mercocidades. Documentos da Unidade Temática Planejamento Estratégico. Available at: <http://www.mercociudades.org/pt-br/node/2124>. Retrieved on 28 Mar de 20180.

Rede Mercocidades. Documentos da Unidade Temática Segurança Cidadã. Available at <http://www.mercociudades.org/pt-br/node/2141>. Retrieved on 28 Mar de 2018p.

Rede Mercocidades. Documentos da Unidade Temática Turismo. Available at <http://www.mercociudades.org/pt-br/node/2213>. Retrieved on 28 Mar de 2018q.

Ruggie, John. International Regimes, Transactions, and Change: embedded liberalism in the postwar economic order. International Organization, 36 (2): 379-415, 1982.

Pachalski, Lia J. Entrevista concedida a Glaucia Julião Bernardo. Curitiba, 01 mar 2018.

Sassen, Saskia. Cities and communities in the global economy: Rethinking our concepts". American Behavioral Scientist, 39 (5): 629-639, 1996.

Slaughter, Anne-Marie. A New World Order. Princeton, Princeton University Press, 2008. 
Soja, Edward. Algunas consideraciones sobre el concepto de ciudades región globales. Ekonomiaz, n. 58, $\quad$ p. 44-75, $2005 . \quad$ Available at $<$ http://www1.euskadi.net/ekonomiaz/taula4_i.apl?REG=732>.

Silva, Pedro Câncio da. Souza, Suzana Bleil de. Práticas de Integração nas Fronteiras: Temas para o Mercosul. Ed. da Universidade/UFRGS, Instituto Goethe/ICBA, 1995.

Souza, Edson; Brites, Walter. Dinâmicas urbanas em cidades gêmeas impactadas por hidrelétricas. Ponta Grossa: Terra Plural 11 (2): 271-290, 2017.

Todo El Campo. Botana impulsa merco regiones y pide 'menos soberanía y más armonía en las fronteras'. 2015. Available at <http://www.todoelcampo.com.uy/espanol/botana-impulsa-mercoregiones-y-pide-quot-menos-soberan-iacute-a-y-m-aacute-s-armon-iacute-a-en-las-fronterasquot-15?nid=20594>. Retrieved on 23 Mar 2018.

Torrecilha, Maria Lucia. A gestão compartilhada como espaço de integração na fronteira Pedro Juan Caballero (Paraguai) e Ponta Porã (Brasil). Anais do I Congresso Brasileiro de Geografia Política, Geopolítica e Gestão do Território, 2014. Rio de Janeiro. Porto Alegre: Editora Letra1; Rio de Janeiro: Rebrajeo, pp. 937-949, 2014.

Torrecilha, Maria Lúcia. A gestão compartilhada como espaço de integração na fronteira: Ponta Porã (Brasil) e Pedro Juan Caballero(Paraguai). Tese (Doutorado)- Faculdade de Filosofia, Letras e Ciências Humanas, Universidade de São Paulo, São Paulo, 2013.

United Cities and Local Governments (UCLG). Level of decentralization by country 2016. Available at <https://www.uclg.org/sites/default/files/plantilla_regiones_en.pdf>. Retrieved on 15 Dez 2017.

Vainer, C. (coord.), Novais Lima JR., P., Oliveira, F. L., Sánchez, F., Bienenstein, G., Oliveira, A., Fix, M., Moura, R., Fernandes, A. M. Grandes projetos urbanos: o que se pode aprender com a experiência brasileira. Relatório técnico. Rio de Janeiro: LILP e IPPUR/UFRJ, 2006. 